\author{
Piotr J. Przybysz \\ - https://orcid.org/0000-0002-6743-2938 \\ University of Gdańsk \\ p.przybysz@ug.edu.pl
}

\title{
STEFAN MORAWSKI AND GRZEGORZ SZTABIŃSKI: SEVERAL COMMENTS ON THE BACKGROUND OF NEO-AVANT-GARDE ART
}

\begin{abstract}
In the article, the author attempts to answer the question to what extent Stefan Morawski's and Grzegorz Sztabiński's views on neo-avant-garde art were convergent or identical.

The first stage on the way to answering this question is the reconstruction of Grzegorz Sztabiński's standpoint on the crisis of culture and the role of neo-avant-garde art in it. The second stage is the reconstruction of Stefan Morawski's contexts of understanding the art practised by Grzegorz Sztabiński. The third one, which provides a fundamental answer to the question posed in the introduction, is the confrontation of the axiological dimension of neo-avant-garde art with postmodernist art. The author argues for axiological convergence in the decisions of Grzegorz Sztabiński and Stefan Morawski in favour of neo-avant-garde art confronted with postmodernist art.
\end{abstract}

Keywords: Stefan Morawski, Grzegorz Sztabiński, neo-avant-garde art, neo-avant-garde artist, postmodernist artist.

Both Stefan Morawski and Grzegorz Sztabiński were genuinely involved in neoavant-garde art. Unlike Morawski, Grzegorz Sztabiński not only reflected on the philosophy of art, aesthetics and art critique, but also practised post-conceptual art which, besides performance and happening, according to S. Morawski, played a key role in this formation. What these two explorers of avant-garde and neo-avant-garde art had in common was the philosophical foundation, both in the case of the philosophical artist and the philosophical researcher of avantgarde art. What divided them was defined by Sztabiński as follows: "practising 
philosophy and philosophising in art (or anti-art) are not the same thing," 1 while Morawski pointed out that "the para-artist and the philosophising theorist therefore walk not so much toward each other as side by side, step by step, burdened by the same burden of a torn civilisation and a torn consciousness that in no way accepts despair and hopelessness." ${ }^{2}$ Both advocated a diagnosis of the crisis of contemporary culture and art that responds to this crisis. Morawski adopted something that is not a universally accepted distinction, that is to call the works of avant-garde art at the beginning of the 20th century the avant-garde or the Great Avant-garde, while he termed the achievements of artists after World War II as neo-avant-garde art. Morawski also defined it as "the avant-garde within avant-garde." ${ }^{3}$ This means that he identified new issues in it that differ significantly from those found in the Great Avant-garde. Additionally, he pointed out that in the case of the neo-avant-garde we are dealing with a decidedly more radical character of many proposals. He thought it was wrong to emphasise the continuity between the two avant-garde formations, claiming that their relationship is as apparent as it is insignificant.

Sztabiński was very accurate in identifying the key points in Morawski's decisions about the avant-garde. In his review Kryzys sztuki - kryzys estetyki (1988) which concerned two books: Na zakręcie od sztuki do po-sztuki (1986) and Zmierz estetyki - rzekomy czy autentyczny? (1987), he formulated what I regard today as an accurate assessment of the role played by avant-garde art in the broader cultural and civilizational context. The above books were a summary of over fifteen years of research. Morawski, studying the category of the cultural crisis in the late 1970s, claimed that, in fact, its most important dimension is an axiological one. In other words, the hitherto prevailing hierarchy of values is giving way to a new one. In his review, Sztabiński reduced the crisis to an illness that produces antibodies in the body. Similarly, a culture in crisis, for Sztabinski indisputably, defends itself by producing antibodies. Thus, antibodies can be reduced to a body's/culture's response to areas affected by crisis. Neo-avantgarde art is such an antibody. Therefore, on the basis of actions opposing crisis phenomena in culture, we can deduce what this crisis concerns. It is analogous with art and aesthetics. Sztabiński pointed to a rare, but very characteristic attitude for Morawski, namely a careful observation of artistic tendencies in the avant-garde. He wrote that "Morawski can often be found in the disorderly and risky atmosphere of avant-garde discussions, exhibitions, happenings, per-

1 G. Sztabiński, Etos awangardy, etos filozofii a postmodernizm, "Przegląd Filozoficzny. Nowa Seria" 1994, no. 4, p. 91.

2 S. Morawski, Rozmyślania bez tytułu, [in:] Sztuka otwarta. Parateatr II, ed. B. Litwiniec, Ośrodek Teatru Otwartego "Kalambur", Wrocław 1982, p. 137.

3 S. Morawski, Awangarda XX wieku - stara i nowa, "Miesięcznik Literacki" 1975, no. 3 , p. 53. 
formances, etc. One of the reasons for undertaking this effort is the conviction that it is through the observation of the latest phenomena in art, most often rebellious, critically referring both to the artistic tradition and to many phenomena in the contemporary world, that, based on the abovementioned principle of observing antibodies, one can discover illnesses relevant to the culture of our times." ${ }^{4}$ Since the neo-avant-garde is a response to crisis, an important issue for Sztabiński was to find an answer to the question what an artist should create in such a situation, what their art should be about. Following Morawski's solutions, he pointed to the following areas: it should replace art with a game with reality, base it on contestation and provocation (from Marcel Duchamp, through gesture and action art, to happening and performance); it should renounce individual values and combine the circulation of aestheticized culture (pop-art, hyperrealism); it should use contemporary technology (luminous-kinetic art, tech-art); it should replace the production of works of art with metaesthetic reflection ${ }^{5}$. I think that the first and the last of the ways of creating art are closest to Sztabiński's choices.

\section{Neo-avant-garde art as a defence of modernist heritage or anticipation of a postmodern formation}

Contrary to what Sztabiński claimed, Morawski did not sympathise with the neo-avant-garde en $b l_{0 c}{ }^{6}$. In the mid 1980s, apart from definitively formulating the theory of the avant-garde and its methodological foundations, he specified and named the causes of the neo-avant-garde formation crisis. This is an integral part of the theory of the avant-garde, which Morawski essentially understood as a critical theory of "cultural deformations, falsities and deficiencies in the socialisation of human beings, including the spirit [...]" concluding work, he distinguished four causes of the neo-avant-garde crisis.

The first, and probably most important one, is the exhaustion of the intellectual and perceptual potential of the successive "-isms" chasing at a frantic

\footnotetext{
G. Sztabiński, Kryzys sztuki - kryzys estetyki, "Studia Filozoficzne" 1988, no. 11, p. 168. See Ibid., pp. 169-170.

6 See G. Sztabiński, Etos awangardy, etos filozofii.., p. 91; G. Sztabiński, Neoawangarda i postmodernizm. Refleksje Stefana Morawskiego nad sztuka wspótczesną, in: Przekraczanie estetyki, ed. Z. Rosińska, A. Łabuńska, Wydział Filozofii i Socjologii Uniwersytetu Warszawskiego, Warszawa 2003, p. 142; I. Lorenc, G. Sztabiński, Logos, Mythos and Avant-garde Art. The Philosophical and Aesthetic Views of Stefan Morawski, in: 20th Century Aesthetics in Poland. Masters and Their Followers, ed. Krystyna Wilkoszewska, Semper, Warszawa 2013, p. 123.

7 S. Morawski, O słabościach praxis neoawangardowej $i$ niedostatkach teorii awangardy, in: Wybory i ryzyka awangardy. Studia z teorii awangardy, ed. U. Czartoryska, R. W. Kluszczyński, PWN, Warszawa - Łódź 1985, p. 22.
} 
pace; the weariness of both perception and inventiveness, a lack of new, fresh and surprising ideas that would surpass the existing ones. Endless attacks on social taboo bastions and until now insurmountable limits, artistic provocations and manifestoes competing in the radicalisation of positions, shaking social opinion and its stereotypical notions, must have led to indifference towards these contesting behaviours and, at the same time, to the exhaustion of ideas for further surpassing borders not yet crossed.

The second one was the absence of the onslaught of successive "-isms", which created a feeling of emptiness and disorientation with regards to the need and sense of doing art. This resulted in the atomisation and privatisation of the artistic environment. Each of the artists, on their own account, assessed the value of the art of rebellion and contestation, of administering justice to contemporary times and being a mirror which helps to make the viewer aware of who we are. A valuation made all the more difficult by the fact that this kind of art was becoming more and more common as a mannerism behind which emptiness was concealed.

The third one is the "taming" of neo-avant-garde art by the mass media. The slogans of one advertisement were transferred into the promotion and commercialisation of another. If the neo-avant-garde proved in its work that everything is acceptable (death on stage, packing and displaying the artist's excrement, etc.), then, on the other hand, it took the form of the slogan that everything is for sale and to be bought. Valuing and classifying was out of the question: intimacy and privacy, transcendence and revolution, alongside opportunism dictated by the rules of the market in line with the expectations of art dealers and managers, were all advertised and acknowledged in a way that made them indistinguishable from one another.

The fourth one is utopias. The neo-avant-garde tried to realise them, e.g. creative life in artistic communities (Living Theatre), consolidation of transcendental experiences through the ability to experience natural states of illumination (Edward Stachura), creation of existential order beyond the mystified and mystifying ideology (Joseph Beuys, Otto Mühl) - they introduced artists to the area of radical anxiety and risk. Can this utopian proposal be realised? What costs and sacrifices will it require? Where to find proven methods that guarantee the achievement of the goal? Will the result correspond with what was imagined and hoped for? The exceptions were those artists who decided not to change, but to adapt.

In 1983, with his work on the crisis of culture and art, Morawski formulated the notion of the crisis of the neo-avant-garde. He strongly emphasised the functioning of two antithetical currents in it: a conformist and a protest one. The former has surrendered itself to the mass media - it is vulgar and flattens the world, and by massaging minds it reduces everything to a sterile dimension 
where truths are formulated in such a way that reception does not pose too many difficulties. The latter is rebellious against the existing reality, homogenisation and artificial unification of values. It constantly tears off masks and denounces the fraudulent mechanisms of social life, striving to achieve maximum self-awareness.

In the 1980s, which perfectly corresponds with his later reflections on postmodern art, Morawski emphasised that the creators of the neo-avant-garde are beginning to reach for old means of (aesthetic) expression, abandoning the effort of self-reflection, withdrawing to their own privacy and concentrating on the present moment. There is growing awareness in this milieu of the meagre effects of the neo-avant-garde and world view proposals resembling "squaring the circle". In the end, the posing of artists as philosophers proved the total dilettantism of the former. Instead of developing hitherto authentic neo-avantgarde phenomena, their "rehashes" appeared. Morawski called such artists legions of people impersonating the neo-avant-garde and making a "cloudy foam" out of it. "[...] these young artists choose, against all appearances of rebelliousness, the most comfortable and easiest attitude. It is better to hide in one's den, as the walls of this terrible civilisation are unbreakable and the artists' immediate predecessors hit their heads against them many times." 8 Thus, the new variety of the 1980s neo-avant-garde in relation to earlier years is epigone. In Morawski's eyes, the neo-avant-garde of the 1980s is interesting in the same way as cowardice and rejection are interesting, but still inspires admiration and reflection despite its gibberish and defeat. He passionately dotted the i's and crossed the t's, writing: "In January 1983, I can say that this type of art sensu stricto and traditional activity [...] seem to me a narcotic eruption of laughter in a ... cemetery" ${ }^{\prime \prime}$. On the other hand, he increasingly specified and differentiated what is included within the concept of the neo-avant-garde and defined what its value depends on. In a text from 1985, he stated that "The neo-avant-garde closes a cultural cycle, develops what was originally manifested in the avant-garde, but also announces something the shape of which cannot be grasped today. If, after avant-garde inspirations dried up, its traces and influences functioned in the interval (the theatre of the absurd, Beckett, nouveau roman) and did not disappear even in the 1950s and 1960s when a new formation had already been constituted, also the new artistic subculture from the years 1955-1980, even if it further stiffens and is deprived of its élan vital, will most probably not disappear completely in the next two decades. In any case, it is not up to us to pronounce a death verdict on it. In fact, this would indirectly be a verdict on

8 Ibid., p. 13.

9 Ibid., p. 14. 
our turbulent and tragic experience from the time of a historical Calvary and civilizational convulsions." 10

At the end of the 1980s, Morawski noticed a current in the neo-avant-garde which anticipated the approaching postmodern art and this was to a large extent what the above criticism referred to. Moreover, according to Morawski, the art whose foundation was contestation was still alive. The basic assumptions of his stance towards postmodernism developed later were put in order in the article Komentarz do kwestii postmodernizmu (1990). In it, the author withdrew from identifying postmodernism with the neo-avant-garde, stating that neo-avant-garde art is a continuation (defence) of modernist heritage or anticipation (and nothing more) of the postmodernist formation. He also defined the genesis of postmodernism, the forerunner of which was neo-avant-garde art described as conformist, as opposed to the works of contestation art. Of the models identified there, the pop-art model, i.e. works of pop- and hyperrealist art, was the closest to the new formation.

\section{Does the avant-garde still exist at all?}

Morawski formulated this question during a lecture given at Galeria Działań in Warsaw, at the opening of an exhibition of works by Jan Chwałczyk, Wanda Gołkowska, Julian H. Raczko and Grzegorz Sztabiński (1993). ${ }^{11} \mathrm{He}$ addressed these words to artists whose works fit into the model of contestation art, whose value, in his opinion, increased especially in confrontation with postmodern art. This is because, according to Morawski, postmodern art was mainly connected with commercialism and the consumer society of postmodern culture. A good example of this are the works of Jeff Koons and Marc Kostabi, who make art for money and popularity. Their art is characterised by unreflectiveness and its value is determined by the laws of the market, where supply and demand play a key role. Morawski pointed out that the avant-garde is not a futile and exhausted formation, and, what is more, it requires intellectual effort, which is difficult to assume in the case of postmodern artists. In the case of the neo-avant-garde, we are dealing with the ethos of the artist outside art. Ethos may be understood in two ways: as the rules of behaviour and coexistence (analogous to decorum), or as a consciously chosen set of values, according to which one should live, regardless of how things are around us. The differences Morawski pointed out between these two notions of ethos are: in the case of the former, obligations are absorbed by the empirics of everyday

10 Ibid., p. 26.

11 See S. Morawski, Artyści awangardy w okresie postmodernizmu, "Exit. Nowa Sztuka" 1993, no. 4, pp. 652-654. 
life, while in the case of the latter - we are dealing with an irremovable tension between how one is and what one can be. ${ }^{12}$ In art, the former understanding of ethos will boil down to a perpetual analysis of similarities and differences in moral values, while the latter will involve a world view analysis of the substructure of a work of art and an analysis through the work of art of its creator. ${ }^{13}$ What follows from ethos thus applied is that "Artists are engaged in creative activity, they have their own way of seeing the world, they still aim to give it a sensory-tactile expression. I would say they think with their skin, they think with their whole selves and, at the same time, beyond art. They go out towards life, towards thought that embraces our reality, that touches the sense of all human existence." ${ }^{14}$ In the conclusion found in the earlier text, Morawski stated that this variety of neo-avant-garde artists are "[...] the diametric pole of neo-decadence and deserve, especially if they themselves sketch this ethos, the highest respect." ${ }^{15}$ During the aforementioned lecture, Morawski included Magdalena Abakanowicz, Jerzy Grotowski, Józef Robakowski, Zbigniew Warpechowski, Jerzy Kalina, Grzegorz Sztabiński, Jan Chwałczyk, Wanda Gołkowska and Julian H. Raczko among these artists in Poland. It was this type of work that Morawski was in favour of and supported. He believed that the attitude of these artists was heroic, as it consciously opposed the hierarchy of values of the consumer society of postmodern culture. It is a choice of the kind of art which I am in favour of and not one that is imposed on me by the market, demand and supply. Morawski's sympathy with these artists also stemmed from the fact that they did not use art to entertain their audiences or to intrusively moralise. They fulfilled the condition of what a neo-avant-garde artist is supposed to be: "[...] they are to be philosophical in their own way. They have to be seekers of what they can offer to others and say: Try! you will follow me or you will leave me... but I propose to you >a venture of heart and mind <, for the artist is to stimulate one to reflect on the world, to ask: what is going on?" 16 Thus, the demands Morawski placed on neo-avant-garde artists were high and fully justified. Such were also the demands he placed on the art practised by Grzegorz Sztabiński.

12 S. Morawski distinguished the following types of postmodern art: kitsch (Jeff Koons, Haim Steinbach), plagiarism (Mark Bidlo, Sherrie Levin, Mark Kostabi), eclecticism (David Salle, E. Cucchi, Richard Prince) and mythography of the postmodern artist (Julian Schnabel, Cindy Sherman, Eric Fischl).

13 See S. Morawski, O etosie artysty poza sztuka, "Znak" 1984, no. 7, pp. 918-928; S. Morawski, Od ethosu sztuki do ethosu artysty poza sztuka, in: Etos sztuki, ed. M. Gołaszewska, PWN, Warszawa - Kraków 1985, pp. 61 - 99. These problems were referred to by G. Sztabiński, Kultura ponowoczesna a etos sztuki, "Zeszyty Artystyczne" 2013, no. 23, pp. 129-134.

14 S. Morawski, Artyści awangardy..., p. 653.

15 S. Morawski, Od ethosu sztuki do ethosu artysty..., p. 99.

16 S. Morawski, Artyści awangardy..., p. 654. 


\section{Grzegorz Sztabiński's art through the eyes of Stefan Morawski}

When we read the exhibition catalogue: Retrospekcja. Grzegorz Sztabiński: obrazy, rysunki, instalacje (7.12.2006-14.01.2007) $)^{17}$, after the introductory text by Grzegorz Sztabiński explaining the essential elements of his art, the second person to "take the floor" is Stefan Morawski. ${ }^{18}$ This can hardly be regarded as a coincidence and I am inclined to believe that his statement was really important for Grzegorz Sztabiński. At the outset, it should be pointed out that this is a critical position. On the one hand, Morawski appreciates the artist's achievements; on the other hand, he shows weaknesses underlying Sztabiński's decisions. Secondly, it ought to be noted that despite the fact that the text had been written ten years before the exhibition Retrospekcja. Grzegorz Sztabiński: obrazy, rysunki, instalacje, it still remained relevant and touched upon the key problems.

Morawski's starting point is the location of Sztabiński's work. It is "a quest for correspondences between the mental landscape and the visual landscape " 19 This is an important decision, as we enter the sphere of competences of an artist who combines two roles. The first one is the role of a problem-solving philosopher who, for the categories of finite-infinite, identity-changing, partwhole, eternal return, seeks the sense, scope and meaning of the concept. The second is that of an artist who seeks the best possible way of representation for these abstract notions in the concrete-sensual area. It is the author's conscious and consistent choice. In order not to trouble the imagination of the viewer, Sztabiński resigns from allegory, symbol and metaphor. As Morawski writes, "the question as to whether an idea can be presented or visualized is at stake here". ${ }^{20}$ Everything is subordinated to this - colour, which is supposed to be a subtle complement; the outline of a tree, which refers to the tree and nothing more. Successive multiplications, permutations and geometric modifications provide an impression of order and from this comes clarity, logic and consistency. This is building a world in which the tension between the counterpoint of the visual and the idea completes the contour of the tree. It is, I believe, a reference to the ultimate instance - reality (res) which subjects all procedures to its own proper verification. In it, the idea of geometry (point, segment,

17 See Retrospekcja. Grzegorz Sztabiński: obrazy, rysunki, instalacje, ed. E. Fuchs, G. Sztabiński, Miejska Galeria Sztuki w Łodzi, Łódź 2006.

18 The text was previously published: S. Morawski, O twórczości Grzegorza Sztabińskiego, exh. cat., Łódź 1986. Stefan Morawski died on 2 December 2004.

19 S. Morawski, [untitled], in: Retrospekcja. Grzegorz Sztabiński: obrazy, rysunki, instalacje, ed. E. Fuchs, G. Sztabiński, Miejska Galeria Sztuki w Łodzi, Łódź 2006, p. 20.

20 Ibid. 
line, parallel, circle, square, rectangle, etc.) meets in structures experienced in nature. These elements can be seen, for example, in snowflakes, crystals or, as in "logical landscapes", contours or silhouettes. It is a clash with purely abstract disciplines, such as mathematics or formal logic, where it is indeed important that the viewer comes into contact with visual elements of reality. Therefore, it is not surprising that we are not dealing here with a literal quotation of qualitative-material features of objects, but with real objects abstracted from certain features. Sztabiński emphasises his choice of the second solution: "In logical landscapes, I choose the second possibility, but never breaking the total bond with nature consisting in partial, even minimal analogy."21 Morawski calls this fascinating combination of two elements "positive actions" (rationally justified ones) and "negative actions" (intuitive, irrational ones). "In the former, reason is the absolute legislator, the latter are directed by intuition which destroys intentional order." 22 The relationships between these two elements are dictated by the rules of the game peculiar to them, which in fact comes down to a game without rules, as exemplified by Poszukiwanie pejzażu absolutnego (1978). Here we reach the point that will be the subject of Sztabiński's further reflections, namely the fallibility of logos as a sphere of human cognition and understanding. It turns out to be unreliable and the mechanisms governing it are not entirely clear and conscious, which "reveals the mysterious <<alchemy〉> of Logos." ${ }^{23}$ Therefore, the search for the absolute landscape "[...] appears to be mythical. Imagination takes its revenge on seemingly omnipotent reason and offers an alliance at the same time," ${ }^{24}$ Morawski states. Hence, Morawski does not believe in Sztabiński's declaration that in his work there is coherence between the iconic sign (what is given in a picture) and its commentary (the idea which it is supposed to be the sign of). This inconsistency is deepened by the implementation which benefits from quality and aesthetic values. "The observer [...] will initially react to the qualities of a work of art, missing what is most important for the artist." ${ }^{25}$ Moreover, it is worth noting that beyond the viewer there is the game the artist plays in the creative process. The game with oneself which Morawski emphasised was particularly important for Sztabiński. It is not about the final result - the work of art - but about the process that leads the artist to it. The accusation of a lack of coherence between the iconic

21 G. Sztabiński, [untitled], G. Sztabiński: Pejzaże Logiczne, GN [nieco gniewnych] Art Gallery of the Association of Polish Artist Photographers and the Regional Centre for Culture, Gdańsk 1978, p. 11 [unnumbered pages].

22 S. Morawski, [untitled]..., p. 20.

23 Ibid., p. 21.

24 Ibid.

25 Ibid., p. 23. 
sign and its commentary is at the same time an appreciation of the goal which the artist sets for himself. One can expect from oneself what is possible, which seems to be a more pragmatic choice and one that does not fall into extremes. In Morawski's eyes, a diametrically opposed attitude is worthy of the highest praise: "Sztabiński attracts me because he wants the impossible." ${ }^{26}$ Morawski's assessment of Sztabiński's work is particularly confirmed by his recent series of drawings featuring the motif of the cross. The artist undertook extremely complicated issues in it. According to Morawski, his aim was to "facilitate sensual understanding of the multiplicity of perceptions of the cross and to find some new iconic equivalent for the symbol stereotype.” ${ }^{27}$ However, the Symbol-Stereotype wins in the reception of this type of artistic proposal, because it usually functions as a specifically simplified image of reality with a clear axiological orientation. This understanding of the stereotype is made more precise by the creator of this concept, Walter Lippmann: "For the most part we do not first see, and then define, we define first and then see. In the great blooming, buzzing confusion of the outer world we pick out what our culture has already defined for us, and we tend to perceive that which we have picked out in the form stereotyped for us by our culture.” ${ }^{28}$ This is a very important addition. It implies that we are not able to free ourselves from the tendency to use stereotypes, which is indicated by the majority of researchers dealing with this issue. Stereotypes serve as ready-made systems of reference, they enable the construction of accepted and expected reality, and facilitate communication. ${ }^{29}$ In Morawski's eyes, the fact "that Sztabiński has decided to work upon ideas which trouble the human most and that he, in his alchemical melting pot, transforms them into a concrete and sensual substance, should be regarded as an endeavour of an extremely valuable quality." ${ }^{30}$ On the other hand, neither Sztabiński, nor Morawski see the effects of neo-avant-garde art as its key value.

\section{On the value of neo-avant-garde art in confrontation with postmodernism}

For Morawski, who is in favour of historical and cultural relativism, relationships between art and the historical and cultural context are of interest. Therefore, he considers the neo-avant-garde in relation to social, political and

26 Ibid.

27 Ibid., p. 24.

28 W. Lippmann, Public Opinion, Macmillan, New York 1922, p. 52 https://www.gutenberg. org/ebooks/6456 (accessed: 28.07.2021).

29 I write more on this subject in: P. J. Przybysz, O nieusuwalności stereotypów i tożsamości zbiorowej, in: Estetyka i filozofia sztuki. Tradycje, przecięcia, perspektywy. Ksiega jubileuszowa z okazji pięćdziesięciolecia pracy naukowej prof. Bohdana Dziemidok, ed. M. Bokiniec, P. J. Przybysz, Wydawnictwo Uniwersytetu Gdańskiego, Gdańsk 2009, pp. 173-184.

30 S. Morawski, [Untitled]..., p. 24. 
ideological issues which constitute its immanent elements. This provides better understanding of what one is dealing with and gives them an opportunity to forecast the way forward. The core of this position is the axiological dimension. It is in this area that each individual, according to his or her own abilities, but also together with others, builds what we call the human in us, as opposed to the fauna and flora. For centuries, art has used aesthetic qualities and values for this purpose. After the Second World War this became problematic and the anxiety, rebellion and opposition expressed in the neo-avant-garde, which Morawski valued, was, among other things, a way of breaking out of the onedimensional existence that Herbert Marcuse wrote about. Therefore, the neoavant-garde becomes not so much an artistic as an ideological movement, characterised by a specific way of thinking and feeling about reality, and proposes specific norms of life for itself.

For Sztabiński, who practised post-conceptual art, the aim was to achieve full coherence between the sign and the idea. It is not about producing a material object, but about transferring one's activity "[...] to the area of conceptual games, [...] beyond the traditional boundaries of the artist's notion," ${ }^{31}$ which has its foundations in the works and theoretical solutions of Joseph Kosuth. What is common here is the conviction that art is a terrain for taking up philosophical issues. In the avant-garde, this happens thanks to a redefinition, as Sztabiński puts it, of the notion of art. The beginnings of defining both art and the artist took place in ancient Greek culture, while a breakthrough came in the Renaissance. The next phase after redefinition is connected with postmodern art and Sztabiński called it undefinition. ${ }^{32}$ It is in strict opposition to redefinition. Values appreciated by Sztabinski in avant-garde art and the artist's ethos, such as authenticity, identity, freedom, order and clarity, are replaced by others. Identity in art is replaced by the aspiration to adapt to the world surrounding the artist. As Zygmunt Bauman diagnosed it, identity ceases to be our skin and becomes our robe "so that it does not cling too tightly to the body, so that when the need or desire arises we can get rid of it as easily as we take off a sweaty shirt." 33 The freedom to be oneself becomes schizophrenic freedom to take elements of foreign creativity and treat them as one's own (Robert Mapplethorpe, Sherrie Levine). This clearly calls authenticity into question, which

31 G. Sztabiński, Inne idee awangardy. Wspólnota, wolność, autorytet, Wydawnictwo Neriton, Warszawa 2011, p. 28.

32 Sztabiński discusses this issue, among others, in: G. Sztabiński, Wstęp. Artysta: definiowanie, redefiniowanie, oddefiniowanie, in: G. Sztabiński, Inne idee awangardy ..., pp. 13-34; G. Sztabiński, Artysta: definiowanie, redefiniowanie, oddefiniowanie, "Dyskurs" 2004/5, no. 2, pp. 159-180; G. Sztabiński, Oddefiniowanie artysty, "Sztuka i Filozofia" 2010, no. 36, pp. 21-29.

33 Z. Bauman, Ponowoczesność jako źródło cierpienia, Wydawnictwo Sic!, Warszawa 2000, p. 143. 
is to say that in this case we are not dealing with the counterfeiting of someone or something and this does not raise any doubts. Clarity, focus and precision are replaced with categories such as relativity, ambiguity, fluidity and irony. "The demise of the avant-garde is also the demise of principles to which the artist must conform, the demise of the search for patterns which are to order behaviour, the demise of the postulate of clearly defining aims and the necessity to justify them. All aspirations, all values are equal in postmodernism, and for this reason one can freely oscillate or drift between them." ${ }^{44}$ The artist's freedom, as Sztabiński particularly emphasized, is the courage to reject authorities, to criticise society while searching for principles that should be universally binding. It is also ideological commitment and a sense of mission, as opposed to the amoral world that is oriented towards material success. "Postmodernism is the demise of such a way of understanding the freedom of the artist" 35 - stated Sztabiński. Pragmatism, ad hoc practicality in behaviour and the choices made replace professed ideas and self-realisation. We witness concepts without meaning, such as: art, an artist, freedom. "As a result, defining and redefining is haphazard, ad hoc and illusory, as the notion of the artist has been definitively redefined." 36

Morawski's diagnoses, in which he uses the category of postmodern artistic consciousness, complement and deepen Sztabiński's solutions. They are not contradictory - they coincide and are identical in the axiological sphere. Morawski's postmodern artistic consciousness is deeply critical of the mythology of avant-gardism. Thus, the myth of the artist-perpetual contester who, thanks to their own talent and artistic intuition, creates visions of better and happier worlds, and draws their strength from disagreement with the existing reality, was the basis of the most valuable achievements in avant-garde and neoavant-garde art, while here it is mercilessly devalued. The more effort is put into living up to the myth of the artist-perpetual contester, the easier it is to dismantle it. In confrontation with the rules of the market game, where a product is a response to created or own consumers' needs, this myth may seem at least not very pragmatic, and in further assessment - melodramatic and romantic. ${ }^{37}$

34 G. Sztabiński, Wstęp. Artysta: definiowanie, redefiniowanie, oddefiniowanie, in: G. Sztabiński, Inne idee awangardy ..., p. 29.

35 Ibid., p. 30.

36 Ibid., p. 34.

37 I use the following texts by Stefan Morawski to reconstruct the consciousness of the postmodern artist: S. Morawski, Mitologiczne aspekty postmodernizmu (jeden z papierków lakmusowych "kryzysu kultury"), "Konteksty" 1996, nos. 1-2, pp. 9-13; S. Morawski, O sytuacji artysty w świece efemeryd, "Twórczość" 1998, no. 3, pp. 86-101; S. Morawski, O mitologii postmodernistycznej i elicie filozoficznej, in S. Morawski, Niewdzięczne rysowanie mapy... O postmodernie(izmie) i kryzysie kultury, Wydawnictwo UMK, Toruń 1999, pp. 248-272. 
The endeavours of postmodern artists who use pastiche, eclectic combining of various stylistic and semantic elements, textual or computer games, as well as include works of foreign artists as their own, or use their fragments, result from the practice of commercial and popular, or parody and nihilistic art. The source of this practice, according to Morawski, is the conviction that art has produced, in the history of its development, works that constitute the ideal of artistic possibilities. Since the most outstanding works have already been created, all that remains is to quote them, use their fragments, or copy them in their entirety and sign them. However, the postmodernist artist does not remain only in the world of quotations, pastiches or parodies of what is recognised and valuable in art. Their work remains in close connection with rules governing the market, where mass culture is the binding language. The creator produces goods that must correspond to current demand (fashion, prevailing tastes and stereotypes). Consumption, on the other hand, must provide pleasure that is not refined, derived from effort invested during contact with a work of art, but resulting from recognition of things known and commonly understood as well as from epidermal "thrills" which should be felt more and more strongly, and more and more often. Introducing questions about the meaning of life, problematizing existential experiences, doing justice to the existing reality and undermining the well-being of the viewer are out of place here and are not the subject of the game that the artist plays with the consumer in the world of supply and demand.

Both S. Morawski and G. Sztabiński understood the role and significance of the artist in neo-avant-garde art in a similar way, although they put different emphasis on it and considered these issues from different angles. The situation was similar in the case of postmodern art and what it entailed. They considered it as degradation of the status of the artist in relation to challenges posed by neo-avant-garde art. Young artists entering this world were in a particularly dangerous situation. Morawski put it as follows: "[...] it is one thing for a young artist, entering the circuit of culture, to choose a path, but it is quite another for an established artist, such as Opałka, Abakanowicz, Bresio, Warpechowski, Robakowski, Berdyszak, Sztabiński or Dłużniewski, who simply confirm and deepen an already revealed creative identity." 38 What united them and what was important for them both, however, was the axiological sphere. Morawski expressed this in words that leave no room for doubt: "If my lecture is received not as the rantings of an old papa, but as a warning against the deluge or even predominance of conformist artistic attitudes, it will have served its purpose." ${ }^{39}$

38 S. Morawski, O sytuacji artysty..., p. 98.

39 Ibid., p. 101. 
I believe that this appeal to resist the temptations of practising art whose value is determined, among other things, by its market price, is still relevant and worth repeating.

\section{BIBLIOGRAPHY:}

Fuchs Elżbieta, Sztabiński Grzegorz ed. (2006) Retrospekcja. Grzegorz Sztabiński: obrazy, rysun$k i$, instalacje, Łódź: the City Art Gallery in Łódź.

Lippmann Walter (1922) Public Opinion, New York: Macmillan.

Lorenc Iwona, Sztabiński Grzegorz (2013) Logos, Mythos and Avant-garde Art. The Philosophical and Aesthetic Views of Stefan Morawski, [in:] 20th Century Aesthetics in Poland. Masters and Their Followers, ed. K. Wilkoszewska, Warszawa: Semper.

Morawski Stefan (1993) Artyści awangardy w okresie postmodernizmu [an exhibition of works of: Jan Chwałczyk, Wanda Gotkowska, Julian H. Raczko and Grzegorz Sztabiński], "Exit”, no. 4, pp. 652-654.

Morawski Stefan (1975) Awangarda XX wieku - stara i nowa, "Miesięcznik Literacki”, no. 3, pp. 53-72.

Morawski Stefan (1989) Coments on G. Sztabiński’s self - presentation, "Leonardo”, vol. 22, no. 2.

Morawski Stefan (1987) Czy zmierzch estetyki?, [in:] Zmierzch estetyki - rzekomy czy autentycz$n y$ ?, vol. 1, ed. S. Morawski, Warszawa: Czytelnik.

Morawski Stefan (1996) Mitologiczne aspekty postmodernizmu (jeden z papierków lakmusowych „kryzysu kultury”), "Konteksty”, nos. 1 - 2.

Morawski Stefan (1985) Na zakręcie od sztuki do po-sztuki, Kraków: Wydawnictwo Literackie.

Morawski Stefan (1999) Niewdzięczne rysowanie mapy... O postmodernie(izmie) i kryzysie kultury, Torun: Wydawnictwo UMK.

Morawski Stefan (1985) Od ethosu sztuki do ethosu artysty poza sztuka, [in:] Etos sztuki, ed. M. Gołaszewska, Warszawa - Kraków: PWN.

Morawski Stefan (1984) O etosie artysty poza sztuka, “Znak”, no. 7, pp. 918-928.

Morawski Stefan (1985) O słabościach praxis neoawangardowej i niedostatkach teorii awangardy, [in:] Wybory i ryzyka awangardy. Studia z teorii awangardy, ed. U. Czartoryska, R. W. Kluszczyński, Warszawa - Łódź: PWN.

Morawski Stefan (1998) O sytuacji artysty w świece efemeryd, “Twórczość”, no. 3.

Morawski Stefan (1986) O twórczości Grzegorza Sztabińskiego, Łódź: An individual exhibition catalogue. 
Morawski Stefan (1982) Rozmyślania bez tytutu, [in:] Sztuka otwarta. Parateatr II, ed. B. Litwiniec, Wrocław: Ośrodek Teatru Otwartego "Kalambur".

Przybysz Piotr J. (2010) Filozofia sztuki Stefana Morawskiego, Gdańsk: słowo/obraz terytoria.

Przybysz Piotr J. (2009) O nieusuwalności stereotypów i tożsamości zbiorowej, [in:] Estetyka i filozofia sztuki. Tradycje, przecięcia, perspektywy. Księga jubileuszowa z okazji pięćdziesięciolecia pracy naukowej prof. Bohdana Dziemidok, ed. Monika Bokiniec, Piotr J. Przybysz, Gdańsk: Wydawnictwo Uniwersytetu Gdańskiego.

Sztabiński Grzegorz (2004/5), Artysta: definiowanie, redefiniowanie, oddefiniowanie, "Dyskurs", no. 2 .

Sztabiński Grzegorz (1994) Etos awangardy, etos filozofii a postmodernizm, "Przegląd Filozoficzny. Nowa Seria”, no. 4, pp. 89-93.

Sztabiński Grzegorz (1984), Filozof i awangarda, [in:] Stefan Morawski - szkic do portretu. Materiały z okazji jubileuszu 60-lecia, Łódź: Art Forum.

Sztabiński Grzegorz (2001) Historia a kontemporaryzm. Problem wartości sztuki w świecie wolnych powiazań, [in:] Wobec świata wartości. Księga pamiatkowa w 45-lecie pracy Profesora Bohdana Dziemidok, ed. H. Szabała, W. Pepliński, Gdańsk: Wydawnictwo Uniwersytetu Gdańskiego.

Sztabiński Grzegorz (2011) Inne idee awangardy. Wspólnota, wolność, autorytet, Warszawa: Wydawnictwo Neriton.

Sztabiński Grzegorz (2020) Inne pojęcia estetyki, Kraków: Universitas.

Sztabiński Grzegorz (1988) Kryzys sztuki - kryzys estetyki, “Studia Filozoficzne”, no. 11, pp.165-172 .

Sztabiński Grzegorz (2013) Kultura ponowoczesna a etos sztuki, “Zeszyty Artystyczne”, no. 23, pp. 129-134.

Sztabiński Grzegorz (2003) Neoawangarda i postmodernizm. Refleksje Stefana Morawskiego nad sztuka wspótczesna, [in:] Przekraczanie estetyki, ed. Z. Rosińska, A. Łabuńska, Warszawa: Wydział Filozofii i Socjologii Uniwersytetu Warszawskiego.

Sztabiński Grzegorz (2010), Oddefiniowanie artysty, “Sztuka i Filozofia”, no. 36.

Sztabiński Grzegorz (1978) Pejzaże Logiczne, Gdańsk: GN Art Gallery of the Association of Polish Artist Photographers and the Regional Centre for Culture.

Sztabiński Grzegorz (1979) Transcendencja 1978 [Stanisław Filko], ed. S. Filko, L. Brogowski, G. Sztabiński, Gdańsk: Galeria gn [nieco gniewnych].

Sztabiński Grzegorz (1992) Transgresja w sztuce awangardowej a twórczość lat osiemdziesiatych, [in:] W kręgu zagadnień awangardy, ed. G. Gazda, G. Szymczyk-Kluszczyńska, Łódź: Acta Universitatis Lodziensis. 


\section{STEFAN MORAWSKI I GRZEGORZ SZTABIŃSKI: KILKA UWAG NA MARGINESIE SZTUKI NEOAWANGARDO- WEJ \\ (streszczenie)}

W artykule autor podejmuje próbę odpowiedzi na pytanie na ile poglądy na sztukę neoawangardową Stefana Morawskiego i Grzegorza Sztabińskiego były zbieżne lub tożsame.

Pierwszym etapem na drodze do udzielenia odpowiedzi na to pytanie jest rekonstrukcja stanowiska Grzegorza Sztabińskiego wobec kryzysu kultury i roli jaką w niej pełni sztuka neoawangardowa. Drugim etapem na tej drodze jest rekonstrukcja kontekstów Stefana Morawskiego rozumienia sztuki uprawianej przez Grzegorza Sztabińskiego. Trzecim, który w sposób zasadniczy udziela odpowiedzi na postawione we wstępie pytanie to konfrontacja aksjologicznego wymiaru sztuki neoawangardowej ze sztuką postmodernistyczną. Autor argumentuje za aksjologiczną zbieżnością w rozstrzygnięciach Grzegorza Sztabińskiego i Stefana Morawskiego na rzecz sztuki neoawangardowej w konfrontacji ze sztuką postmodernistyczną.

Stowa kluczowe: Stefan Morawski, Grzegorz Sztabiński, sztuka neoawangardowa, artysta neoawangardowy, artysta postmodernistyczny.

Piotr J. Przybysz works at the Department of Aesthetics and Philosophy of Culture at the University of Gdansk. He is the author of numerous articles and co-editor of several books, e.g. Filozofia sztuki Stefana Morawskiego (Eng. Stefan Morawski's Philosophy of Art) Together with Anna Zeidler-Janiszewska, he prepared and prefaced with an introduction Stefan Morawski's Wybór pism estetycznych (Eng. Selection of Aesthetic Writings) which appeared in the series: Klasycy Estetyki Polskiej (The Classics of Polish Aesthetics). His current areas of interest include somaesthetics and the aesthetics of sport. 